\title{
THERMAL CONDITIONS OF ADSORPTIVE HEAT STORAGE DEVICE OPERATING IN OPEN-MODE FOR HEATING INFLOWING AIR
}

\author{
Belyanovskaya E.A., PhD, docent, Lytovchenko R.D., postgraduate student, \\ Sukhyy K.M., Dr. Sci. Tech., Prof., Serhiienko Ya.O., postgraduate student, \\ Sukhyy M.P, PhD, Prof., Sukha I.V., PhD, docent \\ State Higher Education Institution «Ukrainian State University of Chemical Engineering», \\ Dnipro, Ukraine
}

Thermal conditions of adsorptive heat storage device operating in open-mode were considered when discharged. The main operating parameters affecting the final temperature of airflow which supplied to ventilated premises are determined on the example of heat storage device based on composite 'silica gel - sodium sulphate'. The main factors which determine a final airflow temperature are confirmed to be initial values of temperature, absolute humidity and speed of airflow which fanned to the adsorbent layer. Algorithm of calculating the operational parameters of adsorptive heat storage device has been further developed. Proposed algorithm involves calculation of diffusion coefficient, mass transfer coefficient, final absolute humidity of airflow, volume of air which passed through adsorbent layer, adsorption, specific adsorption heat and final airflow temperature, then useful heat, heat inputs for operating heat storage device and its efficiency factor are estimated. The adequacy of the proposed algorithm has been confirmed according with experimental data for operating of open mode adsorptive heat storage device. Curves final temperature of inflowing air vs. time of discharge of heat storage device are stated to depend on characteristics of airflow which fanned to the adsorbent layer such as temperature, speed and initial absolute humidity. When these parameters increased, time to achieve plateau, i.e. maximal values of final inflowing air temperature decrease. The dependence of initial values of temperature, absolute humidity, speed of humid airflow and final airflow temperature is shown. Maximal temperatures of at most $65-80{ }^{\circ} \mathrm{C}$ are stated at the initial temperatures and absolute humidity of initial airflow within the ranges of $20-30{ }^{\circ} \mathrm{C}$ and $0.03-0.04 \mathrm{~kg} / \mathrm{m}^{3}$, respectively. The results of the present study can be used for the development of energy-efficient systems and devices for airconditioning in habitual inner space and warehouses.

Key words: adsorptive storage of heat energy, open-type heat storage device, efficiency factor, composite 'silica gel - 'crystalline hydrate'.

Introduction. The crucial expenditures in heat balance of building are thermal losses through enclosing parts of premises and infiltration for the inflow air. Convenient heat, ventilation and air conditioning systems are generally based on vapour compression machines which results in significant electric load. Heating and cooling processes usually perform in surface heat exchangers [1]. Sustaining the convenient level of humidity of the internal air occurs due to changing temperature of air. However absolute humidity of air, i.e. water concentration in the air, remains constant.

Adsorptive heat energy storage and conversion are shown to be promising technologies for heat supply and ventilation system [2 - 6]. Design and performance of such systems involving adsorptive units advance a strong demands on properties of adsorbents used, e.g. maximal adsorption have to surpass $0.5 \mathrm{~kg} / \mathrm{kg}$ and regeneration temperature have to be less than $90-100^{\circ} \mathrm{C}$. Composites 'silica gel - crystalline hydrate' synthesized with sol - gel method are known to correspond with these requirements $[2,7]$. Open-mode devices based on such materials exhibit a potential in heat supply and ventilation. However, introduction of such unit in domestic heat supply and ventilation system can be limited with Sanitary Regulations which resulted from temperature limitation .This fact impedes development of algorithm which allows to determine the air temperature during operating period.

The presented work is focused on determination of basic factors which affects air temperature during operating period of open-type adsorptive heat storage device. To achieve this purpose, the next tasks had been set:

- to determine crucial operating parameters which affect the inflow air temperature during operating period of heat storage device;

- to exhibit correlation between operating parameters and temperature of inflow air during discharge period of adsorptive heat storage unit;

- to estimate the basic requirements to thermal conditions and performance of open-type of adsorptive heat storage unit.

Experimental. The present work is devoted to corellation of performance and inflow air temperature during operating the open-type adsorptive heat storage device. Design of its laboratory prototype is presented in Fig. 1 [8], its length being $0.6 \mathrm{~m}$. 


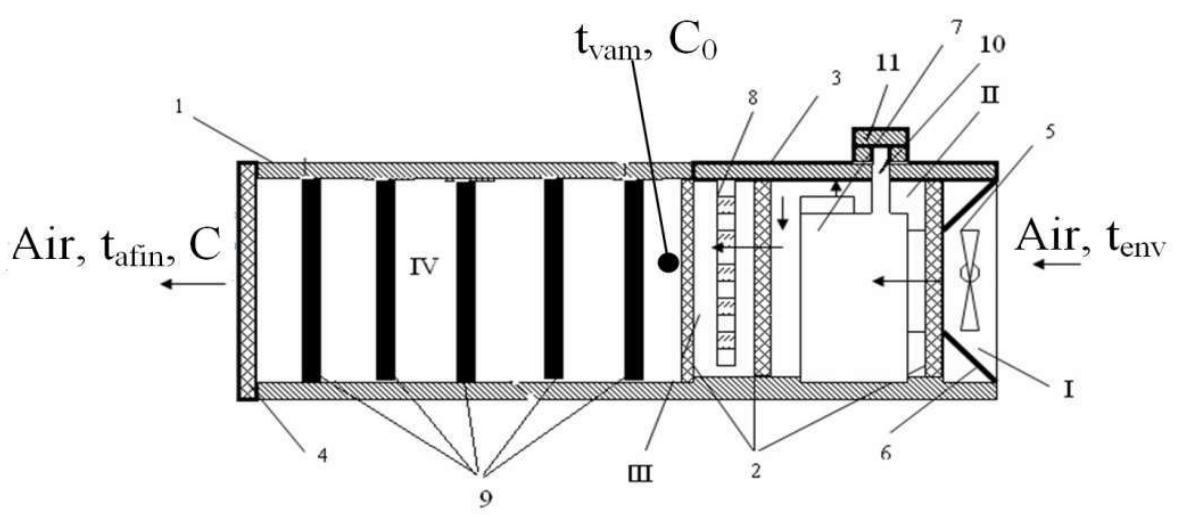

1 - thermal insulated casing; 2 - mesh partitions; 3 - heat-insulated cover; 4 - mesh cover; 5 -fan; 6 - guide casing; 7 - humidifier; 8 - electric resistive heating element; 9 - cassettes with adsorbent; 10 - branch pipe; 11 - cover of a branch pipe [8].

\section{Fig. 1 - Laboratory prototype of heat storage device}

Composites 'silica gel - sodium sulphate' synthesized with sol - gel methods were used as heat storage media. The open-type heat storage device is operated according with two-phase mode. On the first phase external air is pumped by compressor 3 into humidifier 4 , and its relative degree of humidity being increased up to $60-80 \%$. Then humid air is heated in resistance element 5 to $30-40{ }^{\circ} \mathrm{C}$ for speeding the adsorption rate. Then humid airflow is directed into the adsorbent layer. After short-term warm-up of heat storage material $(15 \mathrm{~min}$.) water adsorbed from airflow passed through adsorbent layer. It leads to increasing temperature of both adsorbent and air. Outlet airflow temperature is increased to at least $90^{\circ} \mathrm{C}$. The second step (regeneration) occurs due to pumping the hot air through adsorbent layer which results in warming warm up adsorbent upto temperatures above $90{ }^{\circ} \mathrm{C}$ and desorption of water.

According to these phases algorithm of calculation of operational characteristics has been further developed (Fig. 2).

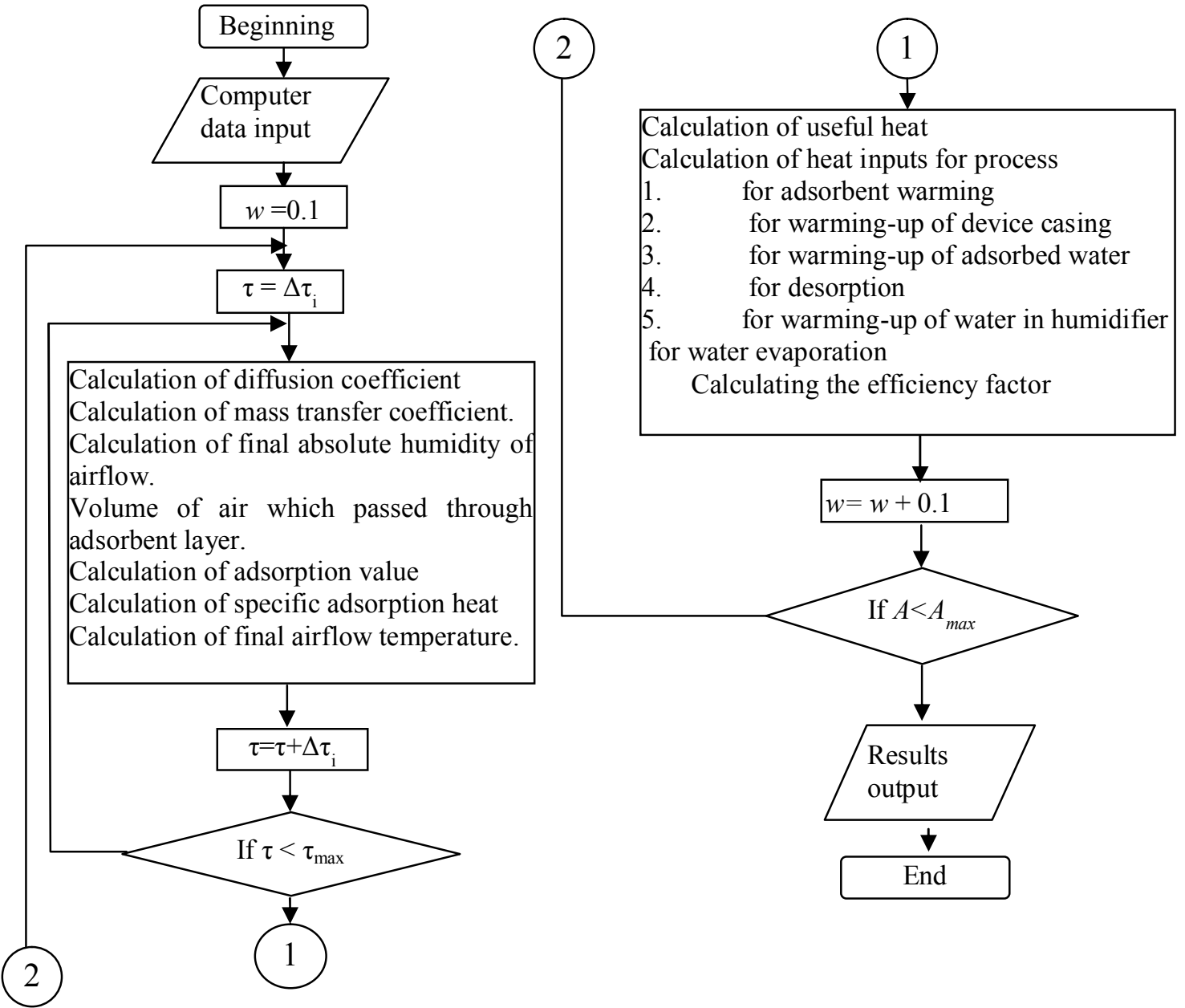

Fig. 2 - Control diagram to calculate temperature of inflowing air and efficiency factor of adsorption heat storage unit operating in open mode 

ered.

As key operating parameters airflow temperature near the outlet heat storage device and efficiency factor are consid-

Airflow temperature neat the outlet heat storage device is determined according to the equation of thermal balance:

$$
\mathrm{t}_{\text {afin }}=\frac{\Delta \mathrm{H}_{\text {ads }} \mathrm{M}_{\text {ads }}+\mathrm{V}_{\text {air }} \cdot \mathrm{t}_{\text {vam }} \cdot\left[4.19 \cdot \mathrm{C}_{0}+\mathrm{C}^{\prime}\right]+\left(\mathrm{M}_{\mathrm{cor}} \cdot \mathrm{c}_{\text {cor }}+\mathrm{M}_{\text {ads }} \cdot \mathrm{c}_{\text {ads }}+4.19 \cdot \mathrm{M}_{\text {ads }} \cdot \mathrm{A}\right) \cdot\left(\mathrm{t}_{\mathrm{vam}}-10\right)}{\mathrm{V}_{\text {air }} \cdot \mathrm{C}^{\prime}+\mathrm{V}_{\text {air }} \cdot 4.19 \cdot \mathrm{C}+\left(\mathrm{M}_{\text {ads }} \mathrm{c}_{\text {ads }}+4.19 \cdot \mathrm{M}_{\text {ads }} \cdot \mathrm{A}+\mathrm{M}_{\mathrm{cor}} \cdot \mathrm{c}_{\text {cor }}\right)}
$$

where $t_{\text {afin }}$ is airflow temperature near the outlet of heat storage device, ${ }^{\circ} \mathrm{C}, \mathrm{V}_{\text {air }}$ is air volume passes through the adsorbent layer, $\mathrm{m}^{3}, \mathrm{M}_{\mathrm{ads}}$ is adsorbent mass, $\mathrm{kg}, \mathrm{M}_{\text {cor }}$ refers to the mass of the device case, $\mathrm{kg} ; \Delta \mathrm{H}_{\mathrm{ads}}$ is adsorption heat, $\mathrm{kJ} / \mathrm{kg}$, $\mathrm{t}_{\text {vam }}$ is temperature of humid air, ${ }^{\circ} \mathrm{C}, \mathrm{C}^{\prime}$ is the volumetric heat capacity of inflowing air, $\mathrm{kJ} / \mathrm{m}^{3} \cdot \mathrm{K}, \mathrm{C}_{0}$ is initial absolute humidity of air, $\mathrm{kg} / \mathrm{m}^{3}, \mathrm{C}$ is final absolute humidity of inflowed air, $\mathrm{kg} / \mathrm{m}^{3}, \mathrm{c}_{\mathrm{ads}}$ refers to special heat of adsorbent, $\mathrm{kJ} / \mathrm{kg} \cdot \mathrm{K}$.

Diffusion coefficient D was calculated by formula given in [2]:

$$
\ln \mathrm{D}=-2.95-6282.02 \cdot \frac{1}{\mathrm{~T}}
$$

where $\mathrm{D}$ is diffusion coefficient, $\mathrm{T}$ refers to an absolute temperature of adsorbent layer.

Mass transfer factor $\beta, \mathrm{s}^{-1}$ is calculated by [2]:

$$
\frac{1}{\beta}=\frac{1}{\beta_{y}}+\frac{1}{\beta_{p}}+\frac{1}{\beta_{\text {c.s. }}}
$$

where $\beta_{y}, \beta_{p}$ and $\beta_{c . s .}$ are the factors mass transfer in gaseous phase, in pores and due to coplanar stirring, $\mathrm{s}^{-}$.

Values of adsorption, final absolute humidity of inflowed air and adsorption heat are calculated by procedure developed earlier [2]. For example, outlet absolute humidity of airflow is determined as [2]:

$$
C=C_{0} \cdot\left(1+e^{\frac{\left.\left[\beta \frac{\left(-\tau \cdot w \cdot C_{0}\right)}{A_{\max }}+H\right]\right]}{w}}\right)^{-1}
$$

where $H$ is the length of adsorbent layer, $\mathrm{m}, A_{\max }$ is maximal water uptake, i.e. limit adsorption, $\mathrm{kg} / \mathrm{kg}$;

Adsorption and air volume are determined by convenient formula

$$
\begin{aligned}
& A=\frac{C_{0}-C}{M_{\text {sor }}} \cdot V_{\text {air }} \\
& V_{\text {air }}=F_{t s} \cdot w \cdot \tau
\end{aligned}
$$

where $F_{t s}$ is transection area of heat storage device, $\mathrm{m}^{2}, w$ is speed of humidified air, $\mathrm{m} / \mathrm{s}, \tau$ is time of discharge, i.e. adsorption, $\mathrm{s}$.

Heat of adsorption is estimated as [2]

$$
\Delta H_{a d s}=\Delta h \cdot A \cdot \frac{1000}{\mu H_{2} O}
$$

where $\Delta \mathrm{h} \cong 60$ is adsorption heat of water vapour, $\mathrm{kJ} / \mathrm{mole} ; \mathrm{A}$ is an adsorption or water uptake, $\mathrm{kg} / \mathrm{kg} ; \mu_{\mathrm{H}_{2} \mathrm{O}}$ is molar mass of water, $\mathrm{g} / \mathrm{mole}$.

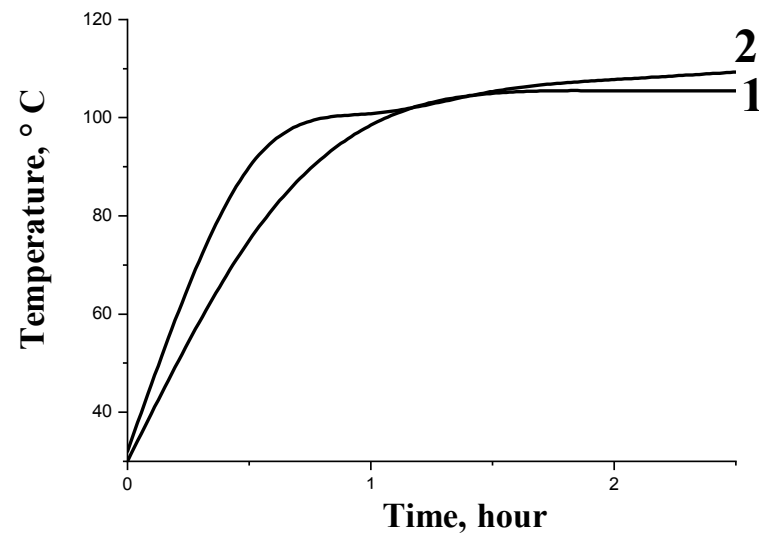

1 - experimental data [7], 2 - results of mathematical modeling

Fig. 3 - Time-temperature curves for final airflow temperature near the outlet of open-type adsorptive heat storage device
Results and discussion. Suggested algorithm was confirmed by experimental data for open-type heat storage device based on composite 'silica gel sodium sulphate' given in [7]. The difference between experimental data and the calculated temperatures does not surpass $5^{\circ} \mathrm{C}$ during 1,5 hours of discharge. So, this algorithm is appropriate for estimating the thermal conditions of open-mode heat storage device. Then performance of the adsorptive heat storage unit based on composites 'silica gel sodium - sulphate' was modeled for a convenient ventilation system of habitual inner space. Mass of adsorbent 'silica gel - sodium sulphate' was suggested to be $96 \mathrm{~kg}$.

Plots of final airflow temperature near the outlet of heat storage device vs. time are given in Fig. 4. Obviously, curves flatten out at rather high times which corresponded with approaching the maximal adsorption values and efficiency factors. Time to achieve this plateau decreases when airflow speed, absolute humidity and airflow temperature increase (Fig. 4a-c, Fig. 5). Temperature of air which sup- 
plied to the ventilated premise grows simultaneously due to increasing the adsorption or water uptake and adsorption heat.

However, airflow temperatures of $80-90^{\circ} \mathrm{Cclose}$ to regeneration temperatures of adsorbent are achieved rather quickly. For example, at airflow temperature of $60{ }^{\circ} \mathrm{C}$ and absolute humidity final airflow temperature is risen to $80^{\circ} \mathrm{C}$ within $1-2$ hours from the beginning of discharge of the device. They are corresponded with values of adsorption no more than $0.2 \mathrm{~A}_{\max }$. That results in rather low values of the efficiency factor.

Moreover, this time strongly depends on airflow speed. As airflow speed increased from 0.1 to $0.4 \mathrm{~m} / \mathrm{s}$, plateau of final airflow temperature decreased nearly by half (Fig. 4a-c).

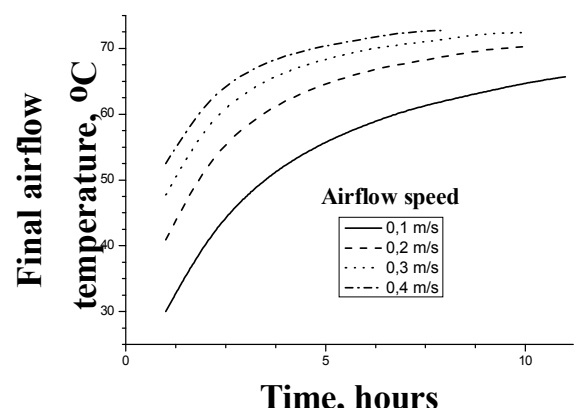

a

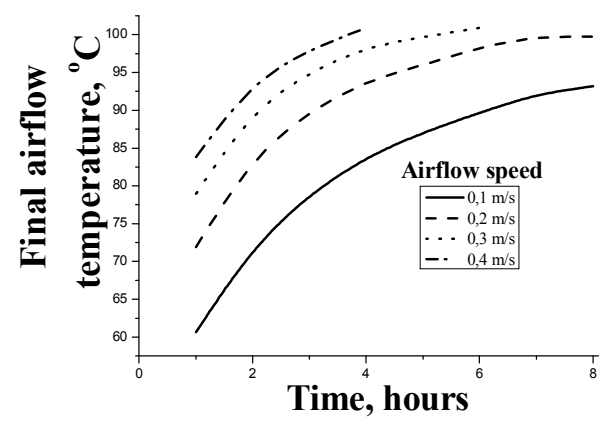

C

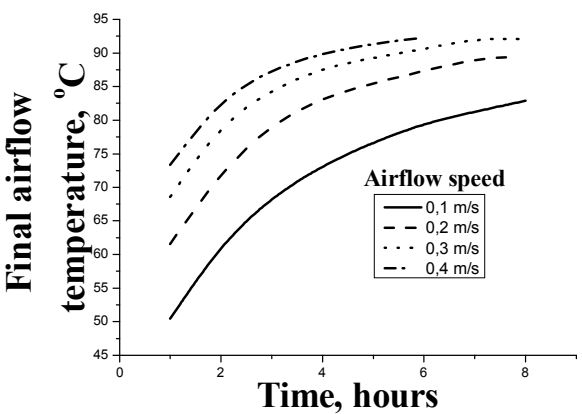

b

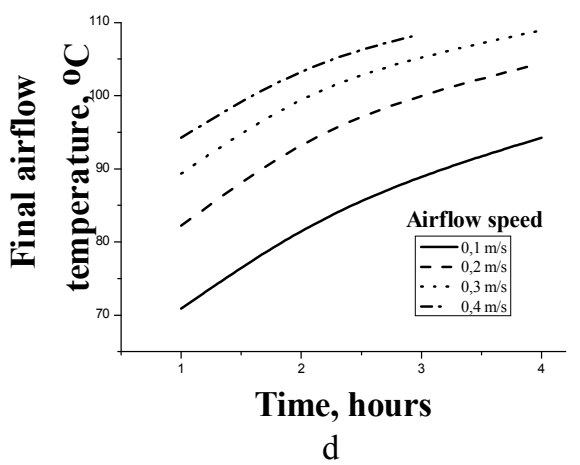

Fig. 4 - Temperature-time curves for heat storage device operating in open mode. Adsorbent 'silica gel $20 \%$ - sodium sulphate $80 \%$ '. Airflow temperature $20{ }^{\circ} \mathrm{C}$ (a), 40 (b), 50 (c) and $60{ }^{\circ} \mathrm{C}$ (d).

Absolute humidity $0.04 \mathrm{~kg} / \mathrm{m}^{3}$

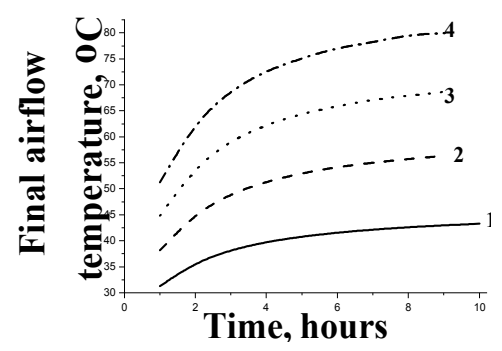

a

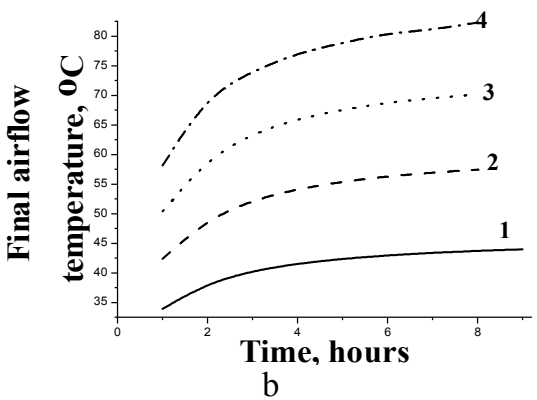

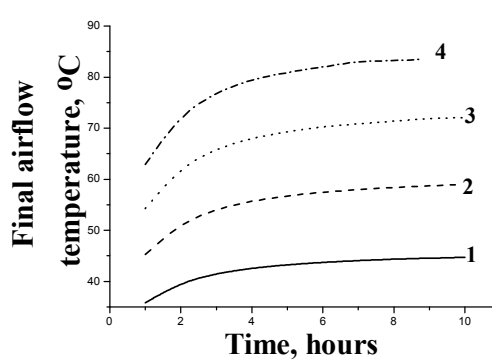

$\mathrm{c}$

Fig. 5 - Temperature-time curves for open-mode heat storage unit. Adsorbent 'silica gel $20 \%$ - sodium sulphate $80 \%$ '. Airflow temperature 30 'C. Airflow speed, m/s: 0.2 (a), 0.3 (b), 0.4 (c). Absolute humidity, $\mathrm{kg} / \mathrm{m}^{3}: 1-0.01 ; 2-0.02 ; 3-0.03 ; 4-0.04$

When temperature of inflowing air increased to $50-60{ }^{\circ} \mathrm{C}$, final temperatures of inflowed air of $80{ }^{\circ} \mathrm{C}$ can be achieved within $1-2$ hours (Fig. 4c, d). Temperature of adsorbent layer reaches $90^{\circ} \mathrm{C}$, i.e. regeneration temperature.

Obviously, operating parameters of heat storage device should be analyzed. Plateau at temperatures which doesn't surpass $80-90^{\circ} \mathrm{C}$ is observed at the temperatures of initial airflow which supplied to the heat storage device are sustained at $20-30^{\circ} \mathrm{C}$ (Fig. 4a, Fig. 5).

More promising mode is absolute humidity of inflowed air $0.03-0.04 \mathrm{~kg} / \mathrm{m}^{3}$ which are corresponding to maximal values of efficiency factor [2]. Final temperatures of $65-80{ }^{\circ} \mathrm{C}$ are stated to be achieved at the airflow speed $0.4 \mathrm{~m} / \mathrm{s}$ within $6-7$ hours which corresponded with maximal values of efficiency factors $45-50 \%$. As another 
simplest technical solution, falling five-fold of charge and discharge periods can be considered. Under these conditions warm airflow can be supplied to ventilated premises corresponded with Sanitary Regulation.

Conclusions. Thermal conditions of open-mode adsorptive heat storage device were studied. The method of determination of final airflow temperature which supplied into ventilated premises is developed for typical conditions of the ventilation systems for the residential premises. Curves final temperature of inflowing air vs. time when discharged is shown to depend on operational parameters of adsorptive open-mode heat storage device. It was shown that time to achieve plateau or maximal values of inflowing air decreases as temperature, speed and initial absolute humidity of air which supplied to adsorbent layer is increased. The correlation between initial temperature, absolute humidity, speed of humid airflow and final airflow temperature which passed through the adsorbent layer is shown. Maximal temperatures of at most $65-80{ }^{\circ} \mathrm{C}$ are corresponded with the initial temperatures and absolute humidity of initial airflow $20-30^{\circ} \mathrm{C}$ and $0.03-0.04 \mathrm{~kg} / \mathrm{m}^{3}$, respectively. Under these conditions maximal values of efficiency factor of open-mode adsorptive heat storage device is stated.

Acknowledgement

This work was performed within frames of taxpayer-funded research of Ministry of Education and Science of Ukraine (grant number 0119U002243).

\title{
References
}

1. Harmathy, N., Jakšić, Ž., Vatin, N. (2015). Heat Balance Method Application in Building Energy Performance Simulation. Applied Mechanics and Materials., 725-726, 1572-1579. DOI: 10.4028/www.scientific.net/AMM.725-726.1572.

2. Sukhyy, K.M., Belyanovskaya, E.A., Sukhyy, M.P. (2020). Technology Development for Adsorptive Heat Energy Converters: Emerging Research and Opportunities. San Francisco: IGI-GLOBAL, USA. DOI: $10.4018 / 978-1-7998-4432-7$

3. Vasta, S., Brancato, V., La Rosa, D., Palomba, V., Restuccia, G., Sapienza, A., Frazzica, A. (2018). Adsorption Heat Storage: State-of-the-Art and Future Perspectives. Nanomaterials., 8, 522 - 535 . DOI: 10.3390/nano8070522

4. Aristov, Yu.I. (2020). Review of adsorptive heat conversion/storage in cold climate countries. Appl. Therm. Eng., 180. P. 115848. DOI: 10.1016/j.applthermaleng.2020.115848

5. Hong, S.W., Ahn, S.H., Chung, J.D., Bae, K.J., Cha, D.A., Kwon, O.K. (2016). Characteristics of FAM-Z01 compared to silica gels in the performance of an adsorption bed. Appl. Therm. Eng., 104, $24-33$. DOI: $10.1016 /$ j.applthermaleng.2016.05.058

6. Erdogan, M., Bau, U., Bardow, A. (2019). Benchmarking commercial adsorbents for drying air in a packed bed. Appl. Therm. Eng., 160, 113942. DOI: 10.1016/j.applthermaleng.2019.113942

7. Sukhyy, K.M., Belyanovskaya, E.A., Kozlov, Ya.N., Kolomiyets, E.V., Sukhyy, M.P. (2014). Structure and Adsorption Properties of the Composites 'Silica Gel - Sodium Sulphate', obtained by Sol - Gel Method. Appl. Therm. Eng., 64, 408 - 412. DOI: 10.1016/j.applthermaleng.2013.12.013

8. Serhiienko, Ya.O., Belyanovskaya, E.A., Sukhyy, K.M., Kolomiyets, E.V., Sukha, I.V., Sukhyy, M.K. (2020). UA Patent No. 141142. Kyiv: State Enterprise "Ukrainian Intellectual Property Institute"(Ukrpatent).

\section{ТЕПЛОВИЙ РЕЖИМ АДСОРБЦІЙНОГО ПРИСТРОЮ ВІДКРИТОГО ТИПУ ДЛЯ ПІДІГРІВУ ПРИПЛИВНОГО ПОВІТРЯ}

\author{
Беляновська О.А., канд. техн. наук, доцент, \\ Литовченко Р.Д., аспірант, \\ Сухий К.М., д-р техн. наук, професор, \\ Сергієнко Я.О., аспірант \\ Сухий М.П., канд. техн. наук, професор \\ Суха I.B., канд. техн. наук, доцент \\ ДВНЗ «Украйнський державний хіміко-технологічний університет», \\ м. Дніпро
}

\begin{abstract}
Розглянуто тепловий режим адсорбиійного теплоакумулюючого пристрою відкритого типу при розряді. Основні робочі параметри, щзо впливають на кінцеву температуру повітряного потоку, щзо подається до вентильованих приміщень, визначено на прикладі теплового акумулятора на основі композиту «силікагелю - натрій сульфату». Основними факторами, щь визначають кінщеву температуру повітряного потоку, є початкові значення температури, абсолютної вологості та швидкості повітряного потоку, ще направляється до шару адсорбенту. Алгоритм розрахунку експлуатаційних параметрів адсорбиійного теплоакумулюючого пристрою отримав подальший розвиток. Запропонований алгоритм передбачає розрахунок коефічієнта дифузії, коефічієнта масопередачі, кіниевої абсолютної вологості повітряного потоку, об'єму повітря, щзо пройшов через шар адсорбенту, адсорбиії, питомої теплоти адсорбиії та кінцевої температу-
\end{abstract}


ри повітряного потоку, далі проводиться розрахунок корисної теплоти та теплових витрат на експлуатація акумулятора теплової енергї та оиінюється коефіиієнт корисної дї. Адекватність запропонованого алгоритму підтверджена відповідно до експериментальних даних для роботи адсорбиійного теплоакумулюючого пристрою відкритого типу. Зазначається, щз криві кінцевої температури припливного повітря 6 залежності від часу розряду теплового акумулятора залежать від характеристик потоку повітря, шо подається до шару адсорбенту, таких як температура, швидкість та початкова абсолютна вологість. Коли ці параметри збільшуються, час досягнення плато, тобто максимальних значень кінцевої температури припливного повітря зменшується. Показана залежність кінцевої температури припливного повітря від початкових значень температури, абсолютної вологості, швидкості потоку вологого повітря. Максимальні температури підігрітого повітря не більше $65-80^{\circ} \mathrm{C}$ встановлені при початкових температурах

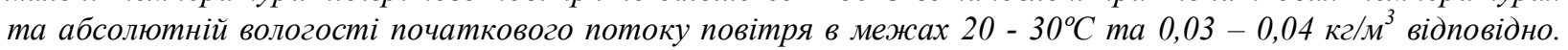
Результати иьього представленого дослідження можуть бути використані для розробки енергоефективних систем вентиляції житлових приміщень та складів.

Ключові слова: адсорбційне акумулювання теплової енергії, тепловий акумулятор відкритого типу, коефіцієнт корисної дії, композитний «силікагель - кристалогідрат».

\section{Список використаної літератури}

1. Harmathy, N., Jakšić, Ž., Vatin, N. Heat Balance Method Application in Building Energy Performance Simulation. Applied Mechanics and Materials. 2015. Vol. 725-726. P. 1572-1579. DOI: 10.4028/www.scientific.net/AMM.725-726.1572.

2. Sukhyy, K.M., Belyanovskaya E.A., Sukhyy M.P. Technology Development for Adsorptive Heat Energy Converters: Emerging Research and Opportunities. - San Francisco: IGI-GLOBAL, USA, 2020. 328 p. DOI: $10.4018 / 978-1-7998-4432-7$

3. Vasta, S. et al. Adsorption Heat Storage: State-of-the-Art and Future Perspectives. Nanomaterials. 2018. Vol. 8. P. 522 - 535. DOI: 10.3390/nano8070522

4. Aristov, Yu.I. Review of adsorptive heat conversion/storage in cold climate countries. Appl. Therm. Eng. 2020. Vol. 180. P. 115848. DOI: 10.1016/j.applthermaleng.2020.115848

5. Hong, S.W. et al. Characteristics of FAM-Z01 compared to silica gels in the performance of an adsorption bed Appl. Therm. Eng. 2016. Vol. 104. P. 24 - 33. DOI: 10.1016/j.applthermaleng.2016.05.058

6. Erdogan, M., Bau, U., Bardow, A. Benchmarking commercial adsorbents for drying air in a packed bed. Appl. Therm. Eng. 2019. - Vol. 160. - P. 113942 DOI: 10.1016/j.applthermaleng.2019.113942

7. Sukhyy, K.M., Belyanovskaya, E.A., Kozlov, Ya.N., Kolomiyets, E.V., Sukhyy, M.P. Structure and Adsorption Properties of the Composites 'Silica Gel - Sodium Sulphate', obtained by Sol - Gel Method. Appl. Therm. Eng. 2014. Vol. 64. P. 408 - 412. DOI: 10.1016/j.applthermaleng.2013.12.013

8. Пат. 141142 UA. МПК F24H 7/04 (2006.01) Адсорбційний акумулятор теплової енергії / Сергієнко Я.О.; Бєляновська О.А.; Сухий К.М.; Коломієць О.В., Суха І.В.; Сухий М.К., ДВНЗ «Український державний хіміко-технологічний університет», заявка № u201908840, заявл. 22.07.2019., опубл. 25.03.2020, бюл. № $6.4 \mathrm{c}$

Отримано в редакцію 20.03.2021

Прийнято до друку 26.06.2021
Received 20.03.2021

Approved 26.06.2021 